\title{
The Portrayal of the First Female Saudi Lawyer: A Multimodal Critical Discourse Analysis of Online Newspaper Articles
}

\author{
Hessah S. Abaalalaa (Corresponding author) \\ College of Languages, Department of Applied Linguistics \\ Princess Nourah Bint Abdulrahman University \\ Riyadh, Saudi Arabia \\ E-mail: hsabaalalaa@pnu.edu.sa
}

Reem A. Alosaimi

English Language Institute

Princess Nourah Bint Abdulrahman University

Riyadh, Saudi Arabia

Received: September 19, 2020 Accepted: October 24, 2020 Published: October 29, 2020

doi:10.5296/ijl.v12i5.17712

URL: https://doi.org/10.5296/ijl.v12i5.17712

\begin{abstract}
This study utilized a developed MCDA (Multimodal Critical Discourse Analysis) framework proposed by Machin and Mayr (2012). It intends to uncover how interceded verbal and visual choices cooperate to show a shift in the construction of the female Saudi lawyer's identity in two articles, Saudi and Iranian. The framework is indebted to Van Dijk's (1998) work in which CDA was viewed as a multidisciplinary field where ideology was the basic theory. The MCDA showed that both articles, i.e., Iranian and Saudi, maintained different ideologies in their representations of the first female Saudi lawyer's achievement and used different linguistic and visual choices to portray this achievement.
\end{abstract}

Keywords: Critical discourse analysis, Ideology, Language, Multimodal critical discourse analysis, Van Dijk 


\section{Introduction}

Analysts of the Critical Discourse Analysis (CDA) field, such as Van Dijk (1993), Fairclough (1995), and Wodak (1997) focused on revealing concealed associations between language, power, and ideology to understand how such discursive discourses are reproduced and maintained to people (Mostafa, 2018). At that point, the field of CDA extended to include mass-interceded texts involving different semiotic modes of communication, i.e., verbal and visual choices which resulted in a different kind of analysis known as Multimodal Discourse Analysis (MDA) (Jones, 2012). MDA was proposed by Kress and Van Leeuwen (1996; 2001) and was lined up with what CDA sought to uncover (Machin, 2016). This alignment introduced the field of Multimodal Critical Discourse Analysis (MCDA).

An increasing number of research studies have been carried out in the area of MCDA. One of the major areas of investigation in this field is the analysis of online newspaper articles. Newspaper articles have various choices of semiotic modes, i.e., linguistic and visual choices (Mostafa, 2018). Most researchers interested in the analysis of newspaper articles have found that, based on newspapers' ideologies, different texts, visuals, and new sources are chosen to represent an incident (Qazi \& Shah, 2017; Mostafa, 2018; Rai, 2018; among others). Hence, additional studies that analyze the strategies employed in newspaper articles are needed. To the researcher's best knowledge, no one has studied online newspaper articles' portrayal of the first female Saudi lawyer. The current study hopes to fill that gap in the literature. It attempts to reveal the construction of the female Saudi lawyer's identity in two articles: Saudi and Iranian. The study utilizes a developed MCDA framework proposed by Machin and Mayr (2012). The framework is indebted to Van Dijk's (1998) work in which CDA was viewed as a multidisciplinary field where ideology was the basic theory. This paper contends that Machin and Mayr's (2012) MCDA would improve our view of how interceded verbal and visual choices cooperate to show a shift in the construction of the female Saudi lawyer's identity in the two Saudi and Iranian articles.

\subsection{Problem Statement}

In the past, female Saudi lawyers were not able to represent their clients in courts. Therefore, they were calling to obtain a lawyer license to practice their career. In 2013 the Saudi Ministry of Justice first granted a lawyer license to a female Saudi lawyer, Bayan Zahran (Fareed, 2018). This present study aims to examine how two online newspaper articles, Saudi and Iranian, portrayed the identity of the first female Saudi lawyer. It seeks to expound upon the following research questions:

(1) How do the two newspaper articles, i.e., Iranian and Saudi, utilize various semiotic modes to construct the identity of the first female Saudi lawyer?

(2) To what extent does Machin and Mayr's (2012) MCDA of the two newspaper articles reproduce or defy dominant discourses of Saudi females in society in reference to Van Dijk's (1998) 'ideological square' framework? 
(3) Are there any differences between the two Iranian and Saudi articles in constructing hidden ideologies concerning the constructing of the identity of the first female Saudi lawyer?

\subsection{Importance of the Problem}

The study aims to reveal the construction of the female Saudi lawyer's identity in two online newspaper articles, Saudi and Iranian, by utilizing Machin and Mayr's (2012) MCDA framework. This paper contends that Machin and Mayr's (2012) MCDA framework would improve our view of how interceded verbal and visual choices cooperate to show a shift in the construction of the female Saudi lawyer's identity in the two Saudi and Iranian articles.

\subsection{Literature Review}

Research on newspaper editorials, as an independent genre, was a discourse analysis topic that drew scholars' attention in the field of CDA. Flower (1991), whose work was significant with respect to analyzing editorials' discourse, proposed three dimensions as a critical outline for examining that discourse: the source, the addressee, and the referent. Flower (1991) believed that what editorials have in content are "ideas" and not facts able to reproduce such discursive sources (Flower, 1991, p. 1). Similarly, Van Dijk (1993) suggested that editorials reflect their own ideologies and opinions. He proposed a theoretical framework for CDA that includes mental representations of social function, cognitive constructions, and discursive reproductions. While Flower (1991) focused on linguistic strategies, Van Dijk (1993) was concerned with text interpretation and production. To him, ideology took on a crucial position, as it functions to direct people for or against (Lihua, 2009).

Moreover, because editorials are considered public discourse, Lihua (2009) constructed a discourse analysis model that included both modal expressions and attitude to examine how power is negotiated and practiced in editorial discourse. Studies in the field of CDA, therefore, were interested in unfolding newspaper articles' strategies for constructing a certain identity. Mostafa's (2018) paper examined how two national and international newspaper articles represented the achievement of a bronze Olympic medalist, Sara Ahmed. The author sought to examine how the two articles constructed the Arab female athletic identity. The framework of Multimodal Critical Discourse Analysis (MCDA) proposed by Machin and Mayr (2012) was the methodological framework used for data analysis. The findings indicated that both national and international articles portrayed Arab female athletes as "active social actors" (Mostafa, 2018, p. 66). However, the international newspaper focused on the traditional challenges and other difficulties Arab women face when it comes to sport. Another research paper was that of Rai (2018). The study analyzed the discursive representation of the Bhutanese and how their issues are discussed online. Rai (2018) utilized a critical discourse analysis approach, i.e., a socio-cognitive framework, focusing on the concept of "representation" (Van Dijk, 1995). The results suggested that the articles published about the selected site depicted Bhutanese individuals as "responsible and generous" and worked to enhance peoples' mutual understanding of them (Rai, 2018, p. 1). The author also suggested that the news articles were "critical of politicians" (Rai, 2018, p. 1). Qazi \& Shah's (2017) paper was another study that sought to examine identity 
construction in newspaper articles. They investigated the identity construction of Malala Yousafzai, a Pakistani female activist, during two important phases of her life, namely "Taliban's victim" and "Nobel laureate," in two Pakistani English newspapers (Qazi \& Shah, 2017, p. 1). The study used Fairclough's (2001) three-dimensional model for data analysis: 1) description: text analysis, 2) interpretation: the relationship between text and interaction, and 3) explanation: the relationship between interaction and social context (Fairclough, 2001). The results suggested that Fairclough's (2001) framework helped the researchers unfold the hidden ideologies that the newspapers employed to construct the identity discourses of social actors, especially of Malala and the Taliban. It also showed an understanding of power relations between various social groups and stakeholders in Pakistan.

\subsubsection{Machin and Mayr's (2012) MCDA}

Machin and Mayr (2012) developed a detailed model of MCDA. This study will focus on two analysis levels: semiotic choices analysis, and social actor analysis. The first analysis level, i.e., semiotic choices, is concerned with the way in which authors structure the textual and visual choices to construct a social identity. It includes lexical choices and iconographical analysis. Starting with lexical choices, Machin and Mayr's (2012) MCDA referred to Van Dijk's (1993) opinion of implicit meaning. It is through lexical choices in which "the ideological work done in the text and the clear stance of the author" are indicated (Machin \& Mayr, 2012, p. 49). MCDA tends to investigate the following: word connotations, overlexicalization, suppression/lexical absence, structural oppositions/ideological squaring, and quoting. As for iconographic analysis, visual resources combine things that seem hard to express through lexical resources. Machin and Mayr (2012) outlined several things that images could obtain for going beyond lexical denotation, i.e., settings: "i.e., salience as exhibited through cultural symbols, size, color, tone"; poses: "i.e. space, openness vs. closeness, activity vs. stillness, body control, and gaze” (Mostafa, 2018, p. 54), and objects' attributes.

Social actor analysis, the second analysis level, is concerned with how communicators make ideological choices to represent social actors and shape their identities. Machin and Mayr (2012) relied on Van Dijk's (1998) term of ideological squaring because representational choices made by authors and/or other communicators function to align readers with or against people (Machin \& Mayr, 2012). This analysis level includes lexical categorization and visual representation of social actors. Starting with the lexical categorization of social actors, Machin and Mayr (2012) cited the following elements of referential ideological choices for classifying people: personalization vs. impersonalization, individualization vs. collectivization, specification vs. generalization, nomination vs. functionalization: the use of objectivation, anonymization, aggression, pronouns vs. noun, and suppression. As for the visual representation of social actors, Machin and Mayr (2012) considered the idea of how images represented people to imply stereotypes and general ideas. They focused on the size of the frame "i.e., close, medium, or long shot" and angle, "i.e., face to face, side-on, look-down-on, or look-up-to" (Mostafa, 2018, p. 55). Also, visual representations concern individual or group representation as well as visual exclusions. 


\section{Macrothink}

International Journal of Linguistics

ISSN 1948-5425

2020, Vol. 12, No. 5

The portrayal of individuals, groups, and cultural and social norms in media discourse impacts not only personal identities but also social identities (Johnson, David, \& Huey, 2003). Therefore, and due to the importance of the role of media discourse, this current study is carried out to reveal the construction of the female Saudi lawyer's identity in two online newspaper articles, Saudi and Iranian, by utilizing the developed framework of Machin and Mayr's (2012) MCDA, i.e., the two analysis stages.

\section{Method}

\subsection{Data Collection}

Saudi and Iranian articles from Arab News and The Iran Project were chosen to provide the data for this study. The articles were of similar length, i.e., about 700 words each. Both articles addressed the story of Bayan Zahran becoming the first female Saudi lawyer in Saudi Arabia.

\subsection{Data Analysis Procedure}

This research paper adapted the analysis method used in Mostafa's paper (2018). Mostafa (2018) used Machin and Mayr's (2012) MCDA framework. As for the procedure of data analysis, the two analysis stages drawn by Machin and Mayr's (2012) MCDA model are used to answer the research questions regarding (1) semiotic choices and (2) social actor analysis.

The first analysis level is the semiotic choices analysis. Machin and Mayr's (2012) MCDA referred to Van Dijk's (1998) opinion about implicit meanings as reflecting underlying thoughts and ideologies. This study, therefore, investigated the following lexical choices that Machin and Mayr (2012) proposed: word connotations, overlexicalization, lexical absence, and quoting. As for the iconographical analysis, this study investigated what Machin and Mayr (2012) proposed as connotations of meaning: setting, pose, and object's attributes.

The second analysis level is the social actor analysis. Van Dijk's (1998) concept of ideological squaring is used as part of Machin and Mayr's (2012) MCDA framework for classifying/representing people. Van Dijk's (1998) proposed the framework of 'ideological square' as part of his cognitive layer in which "discourse comprehension and production can be analyzed and linked to the context (society)" (Awang, Daghigh, \& Sanatifar, 2018, p. 1). The ideological square framework functions as a polarization through which both negative and positive traits of in-group, i.e., us, and out-group, i.e., them are modified through such sustained discourses (Van Dijk, 1998). Awang et al. (2018) stated that Van Dijk's (1998) polarization of us and them can be revealed through interpreting one of the following general strategies:

a) Positive-Self Representation: representing the in-groups' members (Us) positively, via discourse, by de-emphasizing their negative and emphasizing their positive features;

b) Negative-Other Representation: representing the out-groups' members (Them) negatively, via discourse, by de-emphasizing their positive and emphasizing their negative features. (Awang et al., 2018, p. 2) 
Van Dijk (1998) did not propose within his ideological square framework such syntactic language strategies for ideological representation. However, Machin and Mayr's (2012) MCDA model proposed various ideological representational choices for classifying people in reference to Van Dijk's (1998) concept of ideological squaring. The following elements proposed by Machin and Mayr's (2012) MCDA are used for the social actor analysis level of this study: functionalization vs. nomination and specification vs. generalization. As for the visual representation of the social actor, this study investigated the size of the frame as well as the angle. It also investigated the trait of being an individual or in a group and, finally, visual exclusions.

\section{Analysis}

\subsection{Arab News Article}

\subsubsection{Semiotic Choices Analysis}

\subsubsection{Lexical Analysis}

The Arab news article is loaded with word connotations that show the historic achievement of women being able to practice their law careers and becoming equal to their male counterparts. This starts with the article's headline: "Female lawyers in Saudi courts: 'We are equal to male counterparts", and words such as "after years of being prohibited", "significant victory", "realizing their rights", and "overcome many obstacles". The author of the article emphasized that this new exclusive undertaking was not easily achieved; being considered equal to men was a difficult goal for female Saudi lawyers to achieve. Nevertheless, the author asserted that within this achievement, female Saudi lawyers had the right to "advocate for issues that are not only women-related". The article addressed Bayan Zahran as "the first Saudi woman" who opened a law firm. She was set apart as different from the others by her portrayal as a leader forging a path of achievement for future female Saudi lawyers, thereby making them equal to Saudi male lawyers.

In addition, the article overlexicalizes Zahran's achievement of becoming the first female Saudi lawyer in Saudi Arabia by indicating the obstacles she had to overcome to become the "first Saudi woman to open a law firm". The author of the article indicated that one of the obstacles was society's view of this job's appropriateness for woman and Zahran's presence in courtrooms alongside men. However, Zahran faced such obstacles by focusing solely on her job and on what mattered to her; the article quoted her as saying she was "delivering justice and improving work standards in a good and humanitarian manner". The best decision Zahran made was "ignoring negative feedback". Undeniably, this overlexicalization strategy is functional in framing Zahran as a well-established lawyer who had to overcome many obstacles that were once difficult for Saudi women to face. Thus, her lawyer license was the fruit of Zahran's hard work over the years. An ideological change in the Saudi community can be seen through Zahran's achievement, as a woman, in overcoming the obstacles that Saudi society imposed.

Lexical absence was employed in the article to highlight Zahran's iconic achievement by not referring to the role of her family, friends, and others. This information may be relevant in 
other newspaper articles, yet, the author of Arab news article tended not to mention such facts and focused only on the obstacles Zahran faced and overcome them. The author wanted to suggest that Zahran made her achievement independently and it was her, an individual Saudi woman, who made a victory.

Furthermore, Bayan Zahran was quoted throughout the article to emphasize her outstanding achievement. Zahran asserted that she used to argue her cases through "attorneyship" before she opened her "law firm officially" after granting the law license. The author of the article by the use of this quote, said by Zahran, wanted to show the qualifications and capabilities female Saudi lawyers enjoy before starting using the law license. They were able to practice and argue their cases somehow before they have been given the law license officially. In addition, Zahran's achievement gave female Saudi lawyers rights similar to those of their male counterparts. This was suggested by the author's use of Zahran's quote that "As long as a lawyer, male or female, has the expertise that qualifies him or her to obtain the law license, they can argue any cases without exceptions" Zahran said. Expertise is the only thing that differentiates male and female lawyers from each other in arguing different cases. Gender-discrimination is no longer present after Zahran granted her law license.

\subsubsection{Iconographical Analysis}

The article did not include a photograph of Bayan Zahran in its report. However, another Saudi woman, Dima Talal Al-Sharif, who works as a legal consultant for the Health, Food, and Medicine Department at The Law Firm of Majed M. Garoub, was represented. The image of Al-Sharif appeared directly after the article's headline, representing readers' first encounter with the news. Underneath the image appeared a caption about her career status. New generations and new achievements of female Saudi lawyers started to emerge as the result of Bayan Zahran's becoming the first female Saudi lawyer. She was the one who opened up a law firm, thereby opening doors for future female Saudi lawyers. Zahran's achievement was employed to represent the accomplishments of other Saudi females.

Considering the setting, Dima Al-Sharif was at the foreground of the image. She was sitting down alone in an office. Many books were behind her, emphasizing her salience at the image's forefront. The chosen image depicted a real-time event showing a real-and not fictional-achievement by a female. This gave the image a high degree of credibility. The image, portraying a professional setting, was free of any traditional female attributes. Al-Sharif was represented in a manner such that her law career overruled any stereotypical ideas about female restrictions. In terms of pose, Al-Sharif's image showed activity as opposed to stillness. In addition, the image was rich in color. The tone was bright, and the focus was intensified to overstate the details of Al-Sharif's facial expressions. She was smiling with pride, and her eyes were exuberant.

In terms of the object's attributes analysis, the Arab news article, though it did not explicitly state Al-Sharif's Islamic identity, still revealed this fact through its use of her represented image. Al-Sharif wore a black unitard and a black scarf. Her attributes, whether they were cultural or religious symbols, signified that Al-Sharif has a Muslim identity, which ultimately did not prevent her from achieving her desires and dreams. 
A gaze analysis of Al-Sharif's image suggested that, because Al-Sharif's eyes were opened wide and looking ahead, the author emphasized that a bright future awaited more female Saudi lawyers. Al-Sharif's eyes showed a flame, which was a reflection of light from the camera. This flame illustrated the strength that Saudi women possess and use to deliver justice. Al-Sharif was looking off-frame, which inspired the reviewer to observe her objectively and to consider her thoughts at that time. Many of these features cannot easily be revealed through lexical words but can be captured in one medium image.

\subsubsection{Social Actor Analysis}

\subsubsection{Lexical Classification Analysis}

The Arab News article used a number of representation strategies to construct Bayan Zahran as an effective social actor. The referential ideological choices that the Arab News used to construct Bayan Zahran's identity were as follows:

The article tended to use functionalization terms to refer to Bayan Zahran. These included "a Jeddah-based attorney", "became the first Saudi woman", and "who opened a law firm". A functionalization strategy was used to highlight Zahran's professionality as demonstrated by the fact that she had become the first female Saudi lawyer. In addition, nominated terms were used to represent Bayan Zahran. The author used Zahran's first and second names before giving her the functioned term of "attorney". Her last name, Zahran, was used in the rest of the article.

A focus on gender was employed in referring to Zahran's being hired as a lawyer by a "group of male doctors to get their rights from a hospital they work at". The author's representational strategy involved ideologically squaring Zahran among her male counterparts because she was hired not only by an individual male but by a "group" of male doctors. The author tended to focus on the kinds of cases Zahran undertakes, especially those related to men's issues, to illustrate the fact that giving law licenses to female Saudi lawyers was a worthy decision on the authorities' part. This constructed part of Zahran's identity and emphasized her symbolic achievement-one that aligned her with Saudi male lawyers.

Zahran was specified as an individual who had faced and overcome obstacles to achieve a law license. The author specified Zahran as a role model for future female lawyers. Words such as "criticism do not really mean anything to me", and "what I truly care about is my job, delivering justice, and improving work standards" suggest what upcoming female lawyers should do to achieve what Zahran obtained, i.e., a law license.

\subsubsection{Visual Representation of the Social Actor}

Although Zahran did not appear in a visual representation, the image of a female Saudi consultant named Dima Al-Sharif was used. The article portrayed Al-Sharif in an individual representation. She was the only person in the image. This constructed part of the female Saudi identity of being both individual and independent. The author could have used an image of a group of Saudi women, yet the author did not. Instead, the author emphasized the individual empowerment of female Saudi lawyers. In addition, visual exclusions were used to 
imply an idea. Although the image had been taken in a professional setting, i.e., probably a law firm office, the bookshelf did not appear as a whole. The photographer excluded the bookshelf's ends so that the reviewer would think about the number of books that the shelf held.

\subsection{The Iranian Project Article}

\subsubsection{Semiotic Choices Analysis}

\subsubsection{Lexical Analysis}

The article's headline-"first female law firm opens in Saudi Arabia"-connoted Bayan Zahran's achievement of becoming the first female Saudi lawyer. The article contained many word connotations that showed Zahran's historic achievement. Words such as "the country's first female law firm has opened its doors to protect women's rights in Saudi Arabia", "its founder", "Now Saudi women can seek help, advice, and legal aid from Bayan Mahmoud Al-Zahran", and "the first Saudi woman lawyer" together reflected Zahran's iconic achievement as a Saudi woman. Because Zahran had been granted a law license, the author said that Saudi women can "now" seek help from her, embedding the idea that Saudi women's rights were somehow subjugated in the past. The author emphasized the fact that Zahran's law firm "is ready to fight for the rights of Saudi women". The article also used lexical absence. It did not provide Zahran's case examples, unlike the Arab News article, which indicated that male clients had hired her. Instead, the author focused on showing that Saudi male lawyers could not understand cases related to women: "a task which her male counterpart cannot understand". Thus, according to the article, Zahran would probably handle only women-related issues.

The article quoted Zahran several times. One of the quotes cited people who had supported her on her journey. The author's use of this quote could suggest one aspect of the stereotypical image of a Saudi woman, i.e., family importance. "I am very hopeful and thank everyone who supported me in taking this historic step," Zahran said. Her father was quoted in the article: "This will help all women who couldn't go and speak to male lawyers about their problems". Again, women-related issues were the expected cases that Zahran would argue and for which she had received a law license. The author may want to suggest that being considered equal to their male counterparts is still an issue for female Saudi lawyers.

\subsubsection{Iconographical Analysis}

The article did not include an image of Zahran. However, a group of Saudi women did appear in one medium image. The image preceded the article's headline. Starting with the setting analysis, the image exhibited a normal setting; about five women were overlapped in one image walking along the street. The implication was that Zahran's law firm would "fight" for the rights of those Saudi women. The image's pose analysis showed that the image was one of stillness as opposed to activity. They were represented in an atmosphere of stillness as compared to the professional setting in which Al-Sharif appeared in the Arab News' visual representation. As for the object attributes analysis, the Saudi women who appeared in the image were wearing a full black cover, a niqab, and Jubah. The image reflected their Islamic 
and cultural identities; the author wished to emphasize the fact that Zahran's achievement resembled that of all Saudi women and aligned with Islamic and cultural principles.

\subsubsection{Social Actor Analysis}

\subsubsection{Lexical Classification Analysis}

The Iran Project article constructed Zahran as an exceptional Saudi woman who would fight for the rights of Saudi women. The article represented her as a specific individual, the "founder" of the first female law firm. The author used functionalization terms in referring to Zahran as, for example, a "lawyer" and the "first Saudi woman". This functionalization strategy was employed to connote legitimacy and indicate Zahran's agency. The article linked Zahran's achievement to those of individuals who supported her by, for example, including her father's voice in the article. This can be seen as a representational strategy that the author used to ideologically square Zahran's achievement as a historic step, one in which family played a role in helping her reach that stage.. A Saudi audience, for instance, would believe in the role of family and consider it to be of great importance. The article's author tended to use a functioned term in referring to Zahran's father: "Sheikh Mahmoud Al-Zahran". The word "Sheikh" here meant a person who undertakes a religion position. Thus, the article indicated that a religious father was supporting his daughter-something that Saudi society would respect and value. All this information played a role in establishing Zahran as a well-established lawyer supported by a religious father and, thus, a role model for Saudi women.

\subsubsection{Visual Representation of the Social Actor}

The image in the Iran Project article represented a group of Saudi women as if Zahran's achievement were the accomplishment of every Saudi woman. This strategy of representing a group of women in one medium image at the top of the article and before the headline constructed Zahran's identity as that of an exceptional Saudi woman. An angle analysis of the image revealed angles that could be described as a face-to-face review, yet facial expressions could not be observed, as the Saudi women were wearing the niqab. The author wanted to reflect Zahran's Islamic identity by representing stereotypical Saudi women who will probably be Zahran's clients in the future.

\section{Findings}

Both articles, Iranian and Saudi, used linguistic and visual choices to portray Bayan Zahran's achievement. The representational strategies in both articles constructed Zahran as an exceptional Saudi female whose agency showed a sense of female empowerment. The articles constructed her as a role model for every Saudi woman. The images in both articles, though they were not of Zahran, indicated that Zahran's iconic agency was for every Saudi female.

The MCDA in the Saudi article showed that Saudi females in Saudi society have achieved similar equality to men, as evidenced by Zahran's law license. The article challenged dominant discourses about Saudi females inside Saudi society from the very beginning, with 
its headline "Female lawyers in Saudi courts: 'We are equal to male counterparts'." The implication was that Saudi females have become equal to men in an area commonly subject to masculine hegemony. Saudi society's view of women's work was challenged and no longer reproduced. Zahran overcame such obstacles, i.e., "negative feedback" from society. On the other hand, the Iranian article showed that while Zahran's achievement was legitimate, Saudi females still struggle to attain rights equal to those of men within Saudi society. Most of Zahran's law cases focus on women's issues - "a task which her male counterparts at times cannot understand." The article also referred to one agent who played a role in making Zahran's achievement possible. The Iranian article presented the family role, reproducing, in a sense, a stereotypical image of Saudi women inside Saudi society. Therefore, the MCDA showed that both articles, i.e., Iranian and Saudi, maintained different ideologies in their representations of Zahran's achievement. The Arab News showed that Zahran was an individual Saudi woman and did not mention other voices that could have helped her throughout her journey. The report suggested that in the midst of the rapid change taking place in Saudi society (such as women's empowerment), Zahran was no longer different from men, as she had been hired by male doctors to help them obtain their rights. On the other hand, the Iranian article did refer to a family role and specified her father's status as a religious man, a "sheikh." The article presented the expected ideology of Saudi society, as it referenced both religion and family as elements of Zahran's journey. The article did not provide examples of Zahran's cases, leaving it to the reviewer to realize that the cases would probably focus only on women. The images in both articles employed different ideologies. The image utilized in the Arab News suggested that Saudi society is changing for the better. It portrayed a Saudi woman who works as a consultant while maintaining her Islamic identity; she was wearing a scarf and a Jubah. The implication was that Saudi women are expected to assume professional careers in the future. Similarly, the Iranian article did not portray Zahran in a visual representation; instead, it provided an image that showed Saudi women who were in a normal setting - a group of women walking along the street - and who were incapable of earning professional careers. The represented image could be considered as showing a hidden ideology representing Saudi women's inability of earning such professional careers.

\section{Conclusion}

Utilizing MCDA, both articles, Saudi and Iranian, highlighted Bayan Zahran as an active social actor encouraging other Saudi females to follow her path of achievement and to encourage social practices that naturalize women's empowerment. The Arab News emphasized the struggles that Saudi women face in their attempts to achieve such desires - thereby showing the value of Zahran's historic step. The Iranian Project emphasized other voices, i.e., a family member, to convince readers that the opening of Zahran's law firm would not have been possible without such help. Zahran's identity played a role in adjusting power relations for the realms of gendered ideology. Finally, the findings of this study can be interpreted differently and may not be sustained. 


\section{Macrothink}

International Journal of Linguistics

ISSN 1948-5425

2020, Vol. 12, No. 5

\section{References}

Al-Sulami, M. (2018). Number of female lawyers on the rise in Saudi Arabia. Arab News (Jeddah, Saudi Arabia). Retrieved October 31, 2018, from http://www.highbeam.com/doc/1G1-537701296.html?refid=easy_hf

Berger, A. (2016). A discourse on discourse studies. Society, 53, 597-602.

Daghigh, A., Sanatifar, M., \& Awang, R. (2018). Modeling van Dijk's Ideological Square in Translation Studies: Investigating Manipulation in Political Discourse Translation. TRAlinea Journal, 20. Retrieved from http://www.intralinea.org/archive/article/2290

Dijk, T. A. (1993). Principles of critical discourse analysis. Discourse \& Society, 4(2), 249-283. https://doi.org/10.1177/0957926593004002006

Dijk, T. A. (1995). Discourse semantics and ideology. Discourse \& Society, 6, 243-289.

Dijk, T. A. (1998). Ideology: A Multidisciplinary Approach. London, ECIY ISP.

Fairclough, N. (1995). Critical discourse analysis. The Routledge Handbook of Discourse Analysis. https://doi.org/10.4324/9780203809068.ch1

Fareed, A. (2018). Female lawyers in Saudi courts: "We are equal to male counterparts". Arab News (Jeddah, Saudi Arabia). Retrieved October 31, 2018, from http://www.highbeam.com/doc/1G1-537701296.html?refid=easy_hf

Flower, R. (1991). Language in the news. London: Routledge.

Johnson, M. A., David, P., \& Huey, D. (2003). Beauty in brown: Skin color in Latina magazines. In D. I. Ríos, \& A. N. Mohamed (Eds.), Brown and Black communication: Latino and African American conflict and convergence in mass media (pp. 159-174). Westport, CT: Praeger.

Jones, H. (2012). Discourse analysis: A resource bookfor students. New York: Routledge.

Kress, G., \& Van Leeuwen, T. (1996). Reading images: The grammar of visual design. London: Routledge.

Kress, G., \& Van Leeuwen, T. (2001). Multimodal discourse: The modes and media of contemporary communication. London: Arnold.

Lihua, L. (2009). Discourse construction of social power: Interpersonal rhetoric in editorials of the China Daily. Discourse Studies, 11(1), 59-78.

Machin, D. (2013). What is multimodal critical discourse studies?. Critical Discourse Studies, 10(4), 347-355.

Machin, D., \& Mayr, A. (2012). How to do critical discourse analysis: A multimodal introduction. London: SAGE. 


\section{Macrothink}

International Journal of Linguistics

ISSN 1948-5425

2020, Vol. 12, No. 5

Mostafa, R. (2018). Online newspapers portrayal of Arab female athletes in Rio 2016 Olympics: A multimodal critical discourse analysis. International Journal of Arabic-English Studies, 49-70.

Qazi, H., \& Shah, S. (2018). Identity constructions through media discourses: Malala Yousafzai in Pakistani English newspapers. Journalism Studies, 19(11), 1597-1612. https://doi.org/10.1080/1461670X.2017.128457.

Trew, T. (1979). "What the papers say": Linguistic variation and ideological difference. In R. Fowler et al. (Eds.), Language and control (pp. 117-156). London: Routledge \& Kegan Paul.

Wodak, R., \& Fairclough, N. (1997). Critical Discourse Analysis. In T. A. Van Dijk (Ed.), Discourse as Social Interaction (pp. 258-284). London: Sage.

\section{Appendix}

Appendix A

Arab News Article

Female lawyers in Saudi courts: 'We are equal to male counterparts'

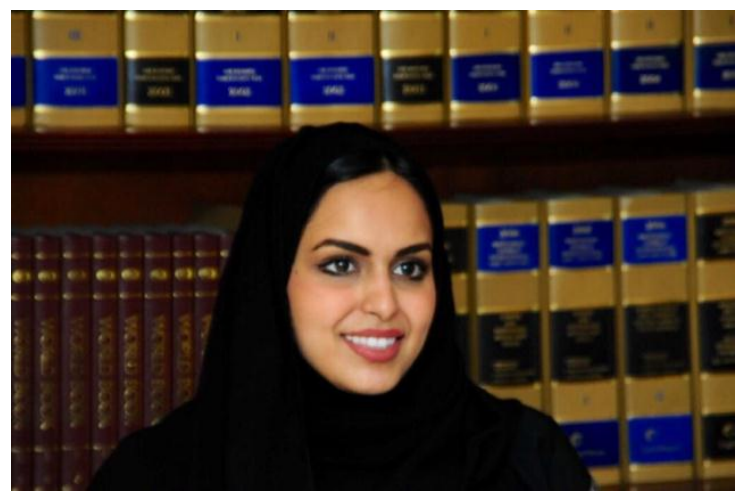

Figure. Dima Talal Al-Sharif, a legal consultant at the Health, Food and Medicine

Department at The Law Firm of Majed M. Garoub.

Updated 21 February 2018

December 29, 201600:00

JEDDAH: After years of being prohibited from appearing in court, female lawyers in 2013 achieved a significant victory in being able to practice law and argue their cases in Saudi courtrooms.

Female lawyers have the right to advocate for issues that are not only women-related, but cover a variety of cases such as commercial, personal and labor affairs. 


\section{Macrothink}

International Journal of Linguistics

ISSN 1948-5425

2020, Vol. 12, No. 5

They were not content to just obtain a license to practice law - they demanded to be included in legal committees and bodies, including the Saudi Bar Association.

On their way to realizing their rights, female lawyers had to overcome many obstacles in law offices and courtrooms to work legally and formally under the Ministry of Justice.

Some did not limit their work to the domestic sphere, undertaking studies and research on legal problems at an international level.

A research paper by lawyer Huda Omar Ba-Shmail, entitled "Investment disputes settlement within the framework of the International Center for Settlement of Investment Disputes (ICSID) and the Protection of Foreign Direct Investment (FDI)," was published in an American banking trade magazine.

Bayan Zahran, a Jeddah-based attorney who in January 2014 became the first Saudi woman to open a law firm, says women's presence in courtrooms long predated the granting of licenses.

"I've been arguing my cases since opening my law firm officially, but even before the license we used to do the same through attorneyship," she said.

Women have been authorized lawyers in Saudi courts for three years. They are recognized, and have rights and duties like their male counterparts based on the Saudi legal system.

Zahran said expertise dictated which cases a lawyer could argue: "As long as a lawyer, male or female, has the expertise that qualifies him or her to obtain the law license, they can argue any cases without exceptions."

Some 90 percent of her clients are women, as women usually prefer someone who can relate to their issues, and Saudi Arabia is a conservative place where they would hesitate to talk freely with male lawyers.

Female lawyers can also get male clients who are willing to hire them. Zahran was recently hired by a group of male doctors to get their rights from a hospital they work at.

Among the obstacles female lawyers have had to deal with is society's view of such a job for women. Some people did not accept their presence in courtrooms alongside men.

Zahran said ignoring negative feedback was the best approach: "Criticism doesn't really mean anything to me. What I truly care about is my job, delivering justice and improving work standards in a good and humanitarian manner."

There are neither specific regulations nor privileges that apply to female lawyers in the Saudi legal system.

Zahran says some fresh graduates have the wrong idea about the nature of their work, whereby female lawyers are treated differently than their male counterparts.

"If women keep in mind that law is all about sticking to the text, and interpreting and using it in a way that serves justice, they can defend their rights as lawyers." 


\section{Macrothink Institute ${ }^{\mathrm{TM}}$}

A number of female lawyers have volunteered to provide legal aid for those unable to hire lawyers in family and labor cases via a charitable initiative organized by the Takamul Investment Company in Jeddah.

The initiative involves training, employment assistance for participating lawyers, and legal services for those who cannot plead for themselves or afford to hire lawyers, says Takamul's president, lawyer Majed Garoub.

As part of the initiative, graduates from regions throughout the Kingdom have been trained by jurists, judges, academics and members of judicial committees.

Volunteers undergo a training program to provide a thousand hours of voluntary work within five years.

Dima Talal Al-Sharif, a legal consultant at the Health, Food and Medicine Department at The Law Firm of Majed M. Garoub, said Saudi female lawyers were "the pioneers of the human rights renaissance in the Kingdom, where they have added much to the prosperity of this profession."

Al-Sharif, who is a member of the Union Internationale des Avocats (UIA), says practicing law is not a profession or a title, but a passion and a challenge to prove oneself.

"This is what I saw and experienced through the participation of a large number of female lawyers at the Takamul initiative," she said.

Al-Sharif expressed her wish that her colleagues get the encouragement and trust of Saudi society so they could give more.

"I wish that the voice of female lawyers in Saudi Arabia reaches greater places in the field of human rights in the Middle East and globally, not just in the Kingdom."

Appendix B

The Iranian Project Article
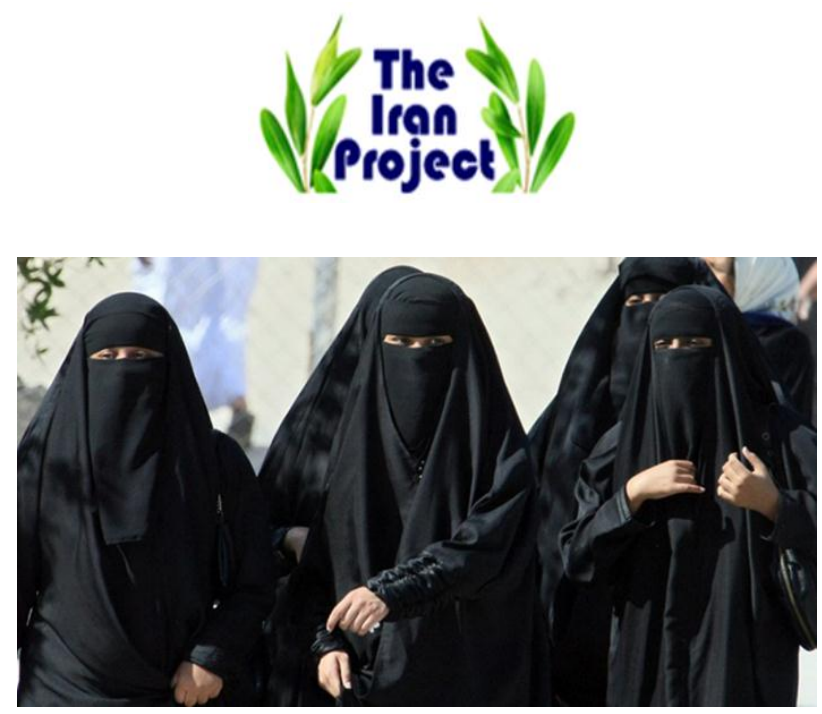
First female law firm opens in Saudi Arabia

The country's first female law firm has opened its doors to protect women's rights in Saudi Arabia, two months after its founder along with three other female lawyers were granted licenses to practice law in the traditionally patriarchal kingdom.

Now Saudi women can seek help, advice and legal aid from Bayan Mahmoud Al Zahran, the first Saudi woman lawyer who launched the female law firm in Jeddah.

Zahran told Arab News that her law firm is ready to fight for the rights of Saudi women and relate women's cases to the court, a task which her male counterparts at times cannot understand or handle.

"I believe women lawyers can contribute a lot to the legal system. This law firm will make a difference in the history of court cases and female disputes in the Kingdom. I am very hopeful and thank everyone who supported me in taking this historical step," Zahran said.

The lawyer also stressed that she is eager to work on labor cases and business disputes involving women but will work with both genders.

"Our activity is not restricted to cases involving only women. Saudi Arabia's legal system treats men and women equally and a lawyer has the right to represent men and women," Zahran told Al Arabiya News Channel.

The launch was attended by a number of Saudi officials and members from the NGO community, including Mazen Batterjee, vice president of Jeddah Chamber of Commerce.

Batterjee stressed the importance of Shariah law Saudi courts, adding that female attorneys should follow the restrictions of the court for hijab while presenting themselves before a judge.

Zahran's father, Sheikh Mahmoud Al-Zahran, praised his daughter's efforts.

"We are very proud of our daughter who stands firm for protection of women's rights. This will help all women who couldn't go and speak to male lawyers about their problems," he said.

Zahran hopes that her firm's example will lead to more female lawyers.

"This is a very positive step toward the Saudi court and justices as right now, we are four female lawyers who got the license, but I am hopeful that in future, the number will increase," she added.

Bayan Zahran, Jihan Qurban, Sarra Al Omari and Ameera Quqani became the first female legal representatives in Saudi Arabia in October, when the country issues licenses, allowing them to change their status from legal consultants to attorneys, thus lifting the ban imposed on female law graduates to practice.

The initial plan of the justice ministry was to allocate licenses to family status cases, but the final decision did not impose any limits on fields of law practice. 


\section{Macrothink}

International Journal of Linguistics

ISSN 1948-5425

2020, Vol. 12, No. 5

Conditions to obtain the license are the same for men and women and include a university degree in law and three years of training.

Women in the ultra-conservative Kingdom of Saudi Arabia usually maintain a traditional place inside the household. Many details in the lives of Saudi women are closely regulated by Sharia law derived from the Koran.

Every adult woman is required to have a close male relative as her 'guardian', who is authorized to make a number of decisions on a woman's behalf, including the right to travel, to start a business, and study at university. Saudi women are prohibited from driving, and are required to cover themselves in public, among other restrictions.

Last October, Saudi women embarked on unprecedented protest measure, by defying kingdom's de facto ban on women driving by getting behind the steering wheel.

As part of the October 26th Women's Driving Campaign, around 60 women got behind their vehicles, some brave enough have even posted their experience on YouTube.

The declaration on the website oct26driving.com has been signed by over 11,000 women.

"Physiological science and functional medicine [found that driving] automatically affects ovaries and rolls up the pelvis," Sheikh Saleh bin Saad al Luhaydan, judicial and psychological consultant to the Gulf Psychological Association, said in reaction to the issue.

He added that the women who drive give birth to children "with clinical disorders of varying degrees."

Many Saudis have expressed their anger in Twitter, mocking the Sheikh's "great scientific discoveries."

\section{Copyrights}

Copyright for this article is retained by the author(s), with first publication rights granted to the journal.

This is an open-access article distributed under the terms and conditions of the Creative Commons Attribution license (http://creativecommons.org/licenses/by/4.0/) 